\title{
Mineralogical Composition and Physical-Mechanical Properties of Dasht-E-Taatrang Zar Sand Deposits (Afghanistan) ${ }^{\dagger}$
}

\author{
Hemayatullah Ahmadi 1,2,*, Atal Yousufi 1,3 and Amir Mohammad Mosazai ${ }^{1}$ \\ 1 Department of Geological Engineering and Exploration of Mines, Faculty of Geology and Mines, \\ Kabul Polytechnic University, Kabul 1001, Afghanistan; yousufi.atal@gmail.com (A.Y.); \\ mosazai@gmail.com (A.M.M.) \\ 2 Department of Remote Sensing and Geographic Information System, Graduate School of Sciences, \\ Eskisehir Technical University, Eskisehir 26000, Turkey \\ 3 Department of Geology and Exploration of Mineral Deposits, Oil and Mining, Institute of Geology, \\ Satbayev University, Almaty 050013, Kazakhstan \\ * Correspondence: h.ahmadi@kpu.edu.af or hahmadi@eskisehir.edu.tr; \\ Tel.: +90-552-266-4876; +93-782-993-001 \\ † Presented at the 3rd International Electronic Conference on Geosciences, 7-13 December 2020; Available \\ online: https://iecg2020.sciforum.net/.
}

Citation: Ahmadi, H.; Yousufi, A.;

Mosazai, A.M. Mineralogical Composition and PhysicalMechanical Properties of Dasht-E-Taatrang Zar Sand Deposits (Afghanistan). Environ. Sci. Proc. 2021, 5, 2. https://doi.org/10.3390/ IECG2020-08832

Academic Editor: Jesus Martinez Frias

Published: 2 December 2020

Publisher's Note: MDPI stays neutral with regard to jurisdictional claims in published maps and institutional affiliations.

Copyright: $\odot 2020$ by the authors. Licensee MDPI, Basel, Switzerland. This article is an open access article distributed under the terms and conditions of the Creative Commons Attribution (CC BY) license (http://creativecommons.org/licenses/by/4.0/).

\begin{abstract}
Sand is a common construction material used for various purposes, e.g., concrete, mortar, render, screed, and asphalt. The usage depends on its fineness, and its fineness is controlled by its mineralogical composition and physical-mechanical properties. This research aims to determine the chemical and mineralogical composition and the physical-mechanical properties of the Dasht-eTaatrang Zar sand deposits within the Qarabagh and Bagram districts of Kabul and Parwan provinces in Afghanistan. To achieve the objectives of this research, a review of the existing literature has been combined with new extensive field works for macroscopic studies and sample collection, and laboratory analyses. In total, 23 samples during two phases of field works were collected and subjected to lab works for XRF, Schlich, and XRD analysis to determine the chemical and mineralogical composition; moreover, sieve and Atterberg analysis, specific gravity, soundness, and alkali-silica reaction tests were performed for characterization of the physical-mechanical properties of the studied samples. The results of the tests show that the Taatrang Zar sand deposits are considered as a suitable construction material, and due to their simple accessibility, the deposits have high potential as a construction material supplier for the Kabul new city project (Dehsabz) in Kabul and adjacent Parwan and Kapisa provinces.
\end{abstract}

Keywords: sand; physical; mechanical; mineralogical; composition; determine

\section{Introduction}

Sand is a crucial component of the construction industry; while the pure type (quartz sand) is used to make glasses and crystal dishes, it is the alluvial (or eolian) type that is most sought after for its use in concrete and cement or for example in pipes and underground pipeline coatings. The Dasht-e-Taatrang Zar sand deposits are located $40 \mathrm{~km}$ North-East of Kabul city, and the deposits extend from the end of the Dehsabz desert (Hotkai hill) up to Niazi and Aroki villages of Bagram district of Parwan province and to the right bank of Panjsher river.

The sands of Taatrang Zar are generally fine-grained, and the sizes of grains vary from about 0.063 to $1 \mathrm{~mm}$ in diameter. These deposits have been formed over a long time in the hillside of the Zin Ghar Mountains, which is situated with an azimuth of 60 degrees in the area and provides a good obstacle for the accumulation of sands. The Dasht-eTaatrang Zar sands have been exploited for use in construction and industrial affairs since 2004. 
In 2006, Amir Mohammad Mosazai and Abdul Salam Kewla professors at the geological engineering and exploration of mines department of Kabul Polytechnic University carried out joint research on these deposits regarding their mechanical characteristics, in which their results have been published in the Science and Technology Journal of Kabul Polytechnic University in 2008. In 2016, one of the Master's students of this department (Mohammad Azim Ahmadi) did his Master's thesis on these deposits. Furthermore, Sadaf Jalal, also one of the Master's students of the aforementioned department in 2018, completed his thesis on the comparison of Dasht-e-Laili sands with Dasht-e-Taatrang Zar Sands, which had a suitable and interesting finding.

Several methods are applied to determine the mineralogical composition of the sand deposit, e.g., X-ray fluorescence, X-ray diffraction, polarized microscopic analysis, and spectrometric analysis [1-4]. The physical-mechanical properties of sands are considered the most important parameters to be studied. Several physical-mechanical properties, e.g., density, hardness, shape, and size of grains, specific gravity, void ratio, and moisture content, are determined using different techniques to characterize the sands used for construction purposes [5-8].

Considering the reviewed literature, this study aims to determine the mineralogical composition and physical-mechanical properties of sand deposits of Dasht-e-Taatrang Zar within Kabul and Parwan provinces in Afghanistan. The findings of this study can significantly contribute to the related construction sectors and can be an effective reference for further detailed studies in academic institutions.

\section{Study Area}

The Dasht-e-Taatrang Zar sand deposits are situated $40-45 \mathrm{~km}$ to the northeast of Kabul city within the hillsides of Zin Ghar Mountains, forming an irregular lens shape that is about 7-8 km long and 3-3.5 km wide. The thickness of the sand layers increases significantly towards the mountains. The initial thickness of the deposits is just several centimeters at the beginning adjacent to QIII clay which covers the surface of the study area and reaches about 35-40 m within the hillsides of Zin Ghar Mountains. Based on the administrative divisions, our study area (Dasht-Taatrang Zar) is placed in the borders of three districts (Qarabagh, Bagram, and Kuhe Safi Districts) between the geographic coordinates of $69^{\circ} 19^{\prime} 3.69^{\prime \prime}$ E- $34^{\circ} 54^{\prime} 50.22^{\prime \prime} \mathrm{N}, 69^{\circ} 20^{\prime} 57.42^{\prime \prime}$ E-34 $53^{\prime} 32.77^{\prime \prime} \mathrm{N}$, and $69^{\circ} 16^{\prime} 20.01^{\prime \prime} \mathrm{E}-$ $34^{\circ} 51^{\prime} 32.98^{\prime \prime} \mathrm{N}, 69^{\circ} 18^{\prime} 8.37^{\prime \prime} \mathrm{E}-34^{\circ} 50^{\prime} 29.86^{\prime \prime} \mathrm{N}$ with the elevation ranges 1480 to $1600 \mathrm{~m}$ (Figure 1). 


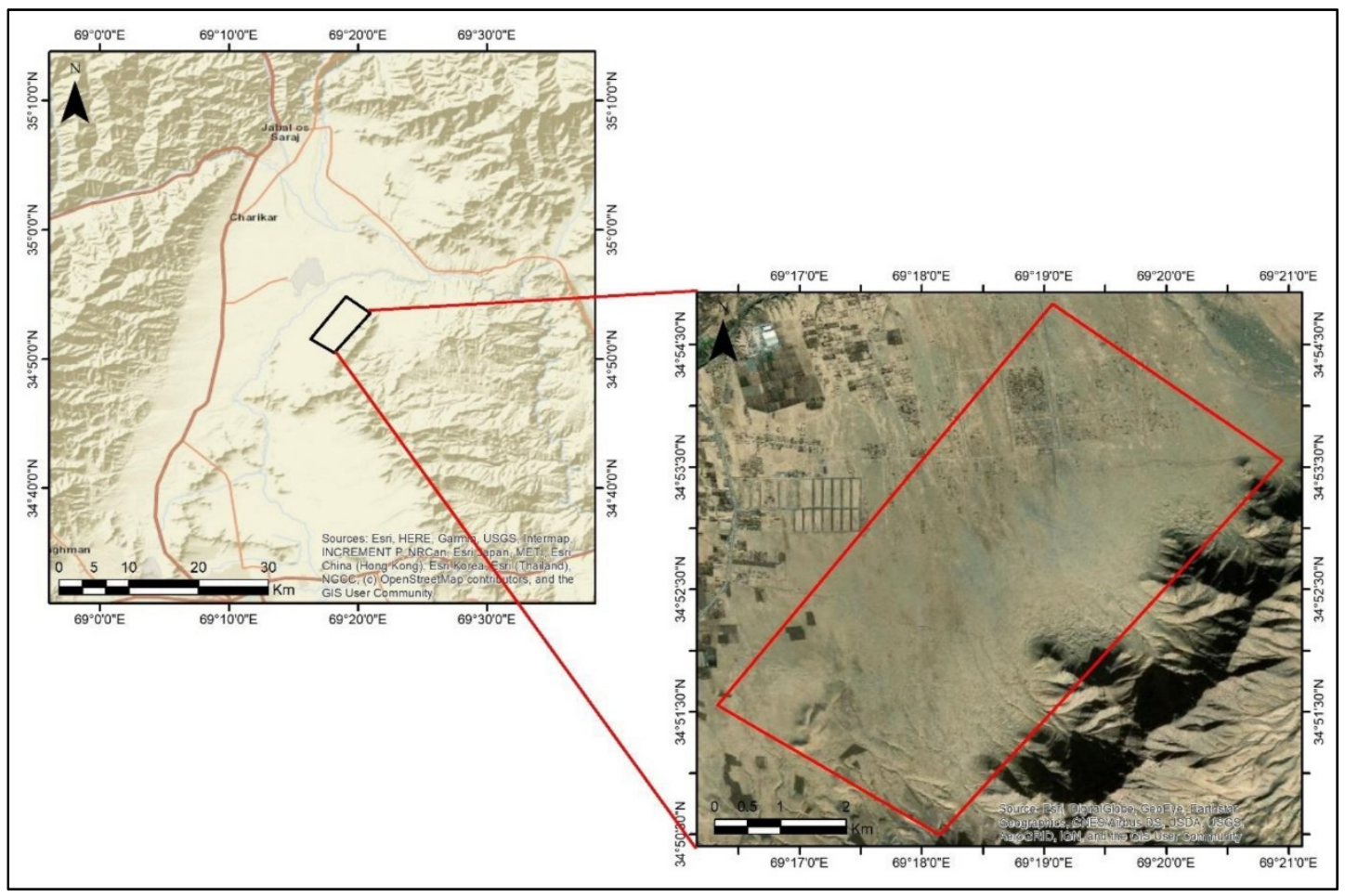

Figure 1. Location of the study area.

\section{Geological Setting}

The Dasht-e-Taatrang Zar sand deposits are situated within the Kabul Block, specifically within the northern part. Although forming a coherent massif, the Kabul Block is highly deformed and consists of at least two distinctly different ancient geologic environments; a Permian to Jurassic marine platform carbonate section and the widespread belt of schistose mélange [9,10]. The Kabul massif is completely fault-bounded. The western edge is at the Chaman-Paghman fault system, and the eastern edge is at the Sarobi and Gardiz faults [10,11] (Figure 2).

The Paghman terrane, west of the Kabul massif, consists of Proterozoic gneiss and granite, Carboniferous to Cisuralian (Early Permian) sandstone and siltstone, Lopingion (Late Permian) to Triassic limestone and dolomite, Rhaetian and Norian shale and sandstone (possibly like that in Nuristan), and Early Cretaceous gabbro and monzonite. The oldest rocks that occur within the northern part of the Kabul Block are Precambrian age metamorphics, e.g., amphibolites, quartzite, marble, and intrusive bodies such as granodiorites [12]. Based on [13], Paleozoic rocks of Ordovician, Silurian, Carboniferous, Permian formations are found around our study area. The rocks are marked as marble, schist, and quartzite (Figure 2). Mesozoic rocks have been identified within the Paghman terrane and the northwestern corner of the northern Kabul block as Triassic formations, including metamorphosed sedimentary rocks, limestone, and dolomite $[13,14]$. Small outcrops of conglomerates and surficial deposits with Paleogene and Quaternary age are exposed within the various parts of the northern Kabul block (Figure 2).

In terms of magmatism, two expanses of plutonic rocks (granodiorite and mafic-ultramafics) are reported with Mesoproterozoic age over and around the Kabul Block. However, these ages are poorly constrained. Ultramafic bodies were also mapped within the Koh-i-Safi area and have been assigned a Cretaceous age, similar to granitic plutons within the Kabul Block and the adjacent regions by [14] (Figure 2). 


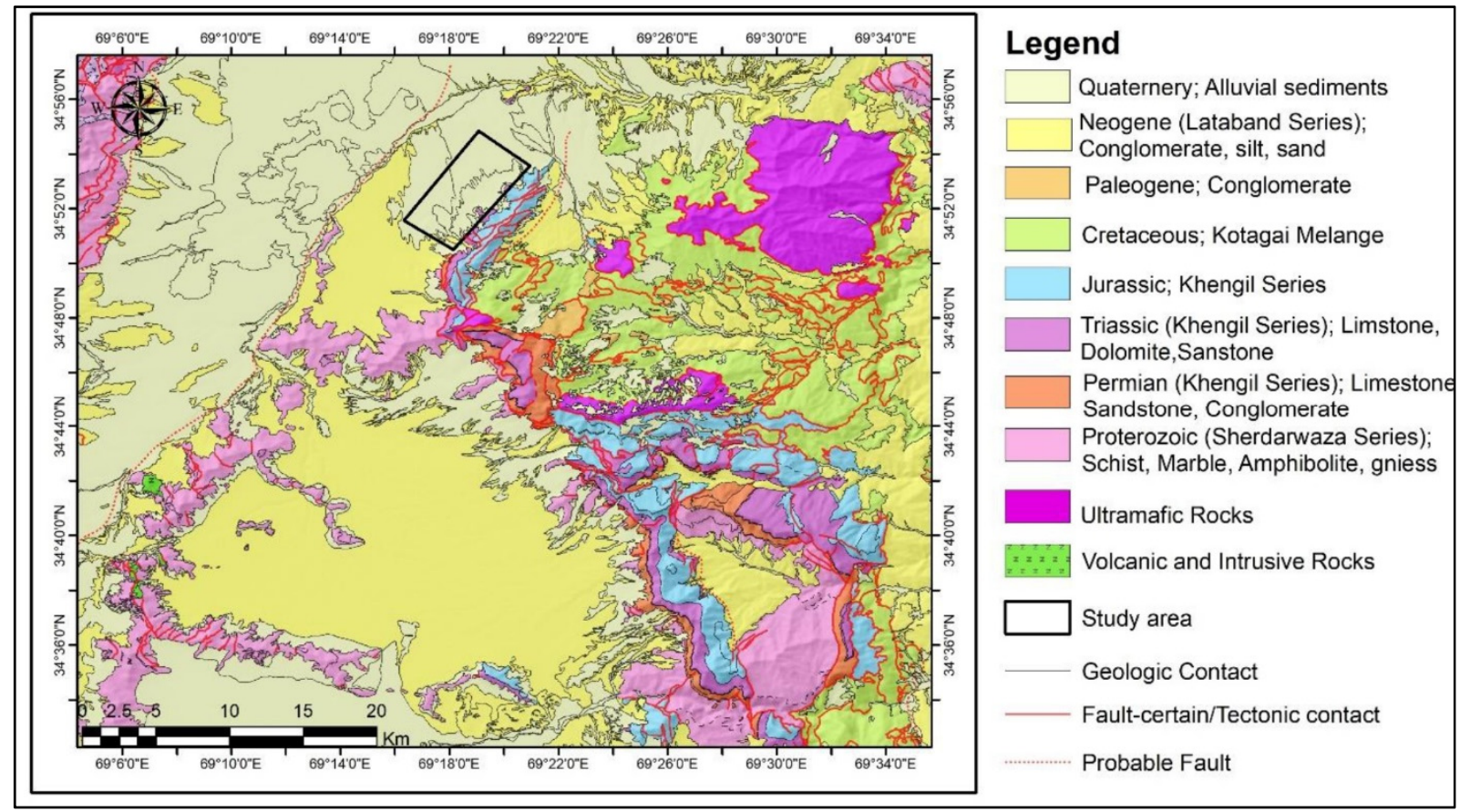

Figure 2. Simplified geologic map of northern Kabul Block modified from [13,15].

\section{Methodology}

This study was carried using the three following methods:

1. Library Method: This method formed the initial part of the study. A comprehensive review of the related literature using research and review articles, thesis, textbooks, authorized websites was carried out. This method was aimed at finding out the unrevealed and weak points of previous studies carried out on the Taatrang Zar sand deposits and also to select the proper analyses to be used for the mineralogical, physical-mechanical properties of sands. General information, including the geologic and tectonic setting of the study area, was also provided by this method.

2. Field Observation Method: Fieldwork and sampling constitute a critical part of such studies. Therefore, field works in this study were carried out through several geologic transverses to study the macroscopic properties and to collect the samples from selected points. The sample collection for lab analysis was conducted within two phases of field works in the study area. The samples were collected randomly and based on the physical, morphological, and structural changes of sands. Twenty-three samples were collected, including 13 samples during the first phase and 10 samples through the second phase, as shown in (Table 1) with their associated coordinates (Figure 3).

3. Laboratory Method: The purpose of this method was the mineralogical, chemical, physical-mechanical analysis of the collected samples to reveal the selected properties of sands. For reliable results, the samples were sent to the Mineralogical Laboratory of Satbayev Institute of Geological Sciences, Kazakhstan, Diamond Geo Engineering Services, and Afghan Geological Survey in Kabul, Afghanistan. For chemical and mineralogical composition, the samples were subjected to X-ray fluorescence, $\mathrm{X}$ ray diffraction (XRD), and Schlich analysis. Several tests, e.g., sieve analysis, Atterberg test, specific gravity test, soundness test, and alkali-silica reaction test, were carried out for the determination of the physical-mechanical properties of the Taatrang Zar sand deposits. 


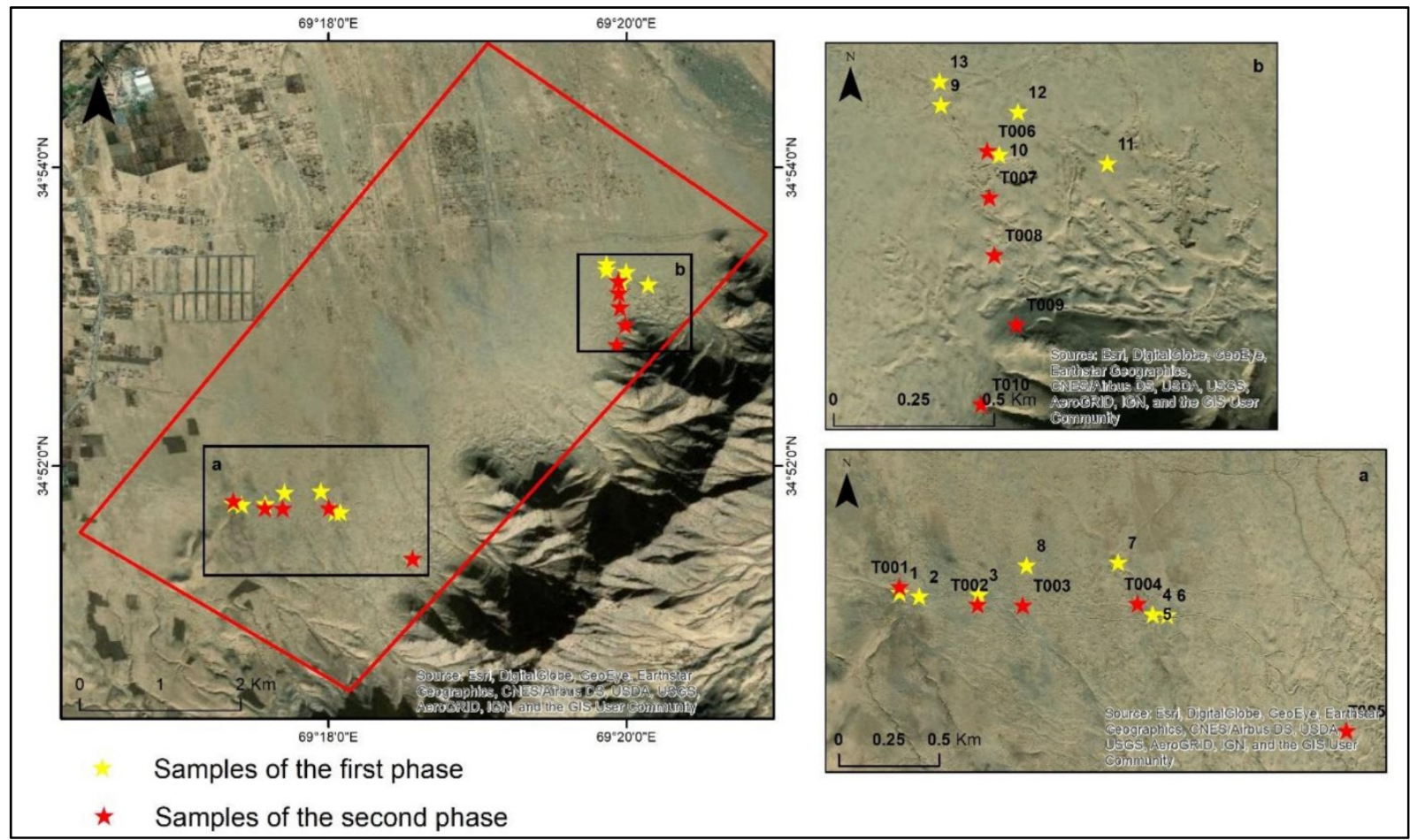

Figure 3. The plan of collected samples during the first and the second phases.

Table 1. Associated coordinates and altitudes of the collected samples.

\begin{tabular}{|c|c|c|c|c|c|c|c|}
\hline \multicolumn{4}{|c|}{ Phase I } & \multicolumn{4}{|c|}{ Phase II } \\
\hline No & Latitude & Longitude & Altitude & No & Latitude & Longitude & Altitude \\
\hline 1 & $34^{0} 51^{\prime} 44.8^{\prime \prime}$ & $69^{\circ} 17^{\prime} 21.9^{\prime \prime}$ & 1586 & T001 & $34^{0} 51^{\prime} 45.7^{\prime \prime}$ & $69^{0} 17^{\prime} 21.9^{\prime \prime}$ & 1674 \\
\hline 2 & $34^{0} 51^{\prime} 44.2^{\prime \prime}$ & $69^{\circ} 17^{\prime} 25.1^{\prime \prime}$ & 1585 & T002 & $34^{0} 51^{\prime} 42.9^{\prime \prime}$ & $69^{0} 17^{\prime} 34.5^{\prime \prime}$ & 1574 \\
\hline 3 & $34^{0} 51^{\prime} 44.5^{\prime \prime}$ & $69^{0} 17^{\prime} 34.7^{\prime \prime}$ & 1584 & T003 & $34^{0} 51^{\prime} 42.8^{\prime \prime}$ & $69^{0} 17^{\prime} 41.8^{\prime \prime}$ & 1580 \\
\hline 4 & $34^{0} 51^{\prime} 41.3^{\prime \prime}$ & $69^{0} 18^{\prime} 2.7^{\prime \prime}$ & 1603 & T004 & $34^{0} 51^{\prime} 43.0^{\prime \prime}$ & $69^{0} 18^{\prime} 0.3^{\prime \prime}$ & 1603 \\
\hline 5 & $34^{0} 51^{\prime} 41.3^{\prime \prime}$ & $69^{0} 18^{\prime} 2.7^{\prime \prime}$ & 1603 & T005 & $34^{0} 51^{\prime} 22.6^{\prime \prime}$ & $69^{0} 18^{\prime} 34.0^{\prime \prime}$ & 1664 \\
\hline 6 & $34^{0} 51^{\prime} 41.2^{\prime \prime}$ & $69^{0} 18^{\prime} 5^{\prime \prime}$ & 1608 & T006 & $34^{0} 53^{\prime} 14.1^{\prime \prime}$ & $69^{0} 19^{\prime} 56.9^{\prime \prime}$ & 1540 \\
\hline 7 & $34^{0} 51^{\prime} 49.7^{\prime \prime}$ & $69^{0} 17^{\prime} 57.1^{\prime \prime}$ & 1591 & T007 & $34^{0} 53^{\prime} 9.4^{\prime \prime}$ & $69^{0} 19^{\prime} 57.1^{\prime \prime}$ & 1549 \\
\hline 8 & $34^{0} 51^{\prime} 49.2^{\prime \prime}$ & $69^{0} 17^{\prime} 42.4^{\prime \prime}$ & 1584 & T008 & $34^{0} 53^{\prime} 3.6^{\prime \prime}$ & $69^{0} 19^{\prime} 57.6^{\prime \prime}$ & 1540 \\
\hline 9 & $34^{0} 53^{\prime} 18.7^{\prime \prime}$ & $69^{0} 19^{\prime} 52.2^{\prime \prime}$ & 1544 & T009 & $34^{0} 52^{\prime} 56.6^{\prime \prime}$ & $69^{0} 19^{\prime} 59.8^{\prime \prime}$ & 1586 \\
\hline 10 & $34^{0} 53^{\prime} 13.7^{\prime \prime}$ & $69^{0} 19^{\prime} 58.1^{\prime \prime}$ & 1553 & T010 & $34^{0} 52^{\prime} 48.6^{\prime \prime}$ & $69^{0} 19^{\prime} 56.3^{\prime \prime}$ & 1604 \\
\hline 11 & $34^{0} 53^{\prime} 12.8^{\prime \prime}$ & $69^{\circ} 20^{\prime} 09^{\prime \prime}$ & 1555 & & & & \\
\hline 12 & $34^{0} 53^{\prime} 18^{\prime \prime}$ & $69^{\circ} 20^{\prime} 00^{\prime \prime}$ & 1552 & & & & \\
\hline 13 & $34^{0} 53^{\prime} 21.1^{\prime \prime}$ & $69^{0} 19^{\prime} 52.1^{\prime \prime}$ & 1545 & & & & \\
\hline
\end{tabular}

\subsection{Chemical and Mineralogical Analysis}

\subsubsection{X-ray Fluorescence (XRF)}

$\mathrm{X}$-ray fluorescence is used to determine the bulk chemical composition of rocks, minerals, and sediments. The elements from fluorine to uranium in the periodic table can be detected by XRF [16,17]. 13 samples from various locations were analyzed using X-ray fluorescence targetting the elements $\mathrm{Mg}$, $\mathrm{Al}, \mathrm{Si}, \mathrm{P}, \mathrm{K}, \mathrm{Ca}, \mathrm{Ti}, \mathrm{Fe}, \mathrm{S}, \mathrm{Cl}, \mathrm{Mn}, \mathrm{Sr}, \mathrm{Ba}$, and $\mathrm{Zr}$. 
The concentrations of these elements in the composition of sand samples are highly variable, the contents ranging from high percentages to PPM levels. The associated results and the percentages of each element, as shown in the original report, are shown in Table 2.

Table 2. Results of XRF analysis of the sand samples collected through the first phase.

\begin{tabular}{|c|c|c|c|c|c|c|c|c|c|c|c|c|c|c|c|}
\hline \multirow{3}{*}{$\begin{array}{c}\text { Sample } \\
\text { No }\end{array}$} & \multicolumn{15}{|c|}{ Elements } \\
\hline & \multicolumn{9}{|c|}{$\%$} & \multicolumn{6}{|c|}{ PPM } \\
\hline & Bal & $\mathrm{Mg}$ & $\mathrm{Al}$ & Si & $\mathbf{P}$ & $\mathrm{K}$ & $\mathrm{Ca}$ & $\mathrm{Ti}$ & $\mathrm{Fe}$ & $S$ & Mn & $\mathrm{Cl}$ & $\mathbf{B a}$ & $\mathrm{Sr}$ & $\mathrm{Zr}$ \\
\hline 1 & 53.58 & 1.99 & 6.44 & 26.81 & 0.14 & 2.59 & 2.45 & 0.72 & 5.02 & 834 & 559 & 666 & 380 & 239 & - \\
\hline 2 & 54.83 & 1.41 & 6.5 & 29.95 & - & 1.66 & 2.52 & 0.36 & 2.61 & 688 & 306 & 240 & 349 & 308 & - \\
\hline 3 & 54.62 & 1.25 & 5.79 & 29.15 & - & 1.46 & 3.85 & 0.41 & 3.13 & 735 & 561 & 261 & 352 & 299 & 153 \\
\hline 4 & 51.18 & 0.87 & 6.74 & 31.32 & 0.15 & 1.18 & 3.22 & 0.53 & 3.288 & 776 & 693 & 230 & 381 & 242 & 334 \\
\hline 5 & 53.65 & 1.13 & 6.62 & 29.55 & 0.11 & 1.48 & 3.59 & 0.44 & 3.19 & 818 & 514 & 367 & 323 & 105 & 169 \\
\hline 6 & 52.96 & 1.23 & 6.3 & 30.62 & 0.14 & 1.39 & 3.12 & 0.29 & 2.71 & 729 & 388 & 315 & 296 & 365 & - \\
\hline 7 & 52.96 & 1.23 & 6.3 & 30.62 & - & 1.39 & 3.12 & 0.29 & 2.73 & - & 388 & 315 & 365 & 296 & - \\
\hline 8 & 54.62 & 1.22 & 5.82 & 29.65 & - & 1.46 & 3.35 & 0.4 & 3.14 & 740 & 556 & 266 & 352 & 294 & 158 \\
\hline 9 & 54.1 & 1.31 & 6.21 & 29.58 & - & 1.62 & 4.36 & 0.47 & 3.61 & 973 & 637 & 572 & 386 & 226 & 237 \\
\hline 10 & 64.8 & 0.95 & 4.98 & 22.3 & - & 1.15 & 2.31 & 0.12 & 1.55 & 625 & 169 & 367 & 136 & 360 & - \\
\hline 11 & 54.62 & 1.25 & 5.79 & 29.15 & - & 1.46 & 3.85 & 0.41 & 3.13 & 735 & 561 & 261 & 352 & 299 & - \\
\hline 12 & 56.95 & - & 6.73 & 29.67 & 0.15 & 1.04 & 3.21 & 0.14 & 1.47 & 866 & 232 & 469 & 349 & 350 & - \\
\hline 13 & 53.26 & 1.31 & 6.21 & 28.74 & - & 1.74 & 4.36 & 0.47 & 3.48 & 971 & 632 & 577 & 482 & 233 & 232 \\
\hline
\end{tabular}

\subsubsection{Schlich Analysis}

Schlich analysis is one of the mineralogical approaches that is used for the identification of mineral concentrations without complicated chemical analysis. This method is mostly used in placer deposits by consideration of physical characteristics of minerals, e.g., density, color, hardness, etc. The sample is divided into different fractions under the mineralogical microscope, then the existing minerals within the fractions are determined based on their physical characteristics. In this study, 13 collected samples were subjected to Schlich analysis to determine the mineralogical composition; the results are shown in Table 3.

Table 3. Results obtained from Schlich analysis for the collected samples through the first phase.

\begin{tabular}{|c|c|c|c|c|c|c|c|c|c|c|c|c|c|c|}
\hline \multirow{2}{*}{ Minerals/Fragments } & & \multicolumn{13}{|c|}{ Samples } \\
\hline & & 1 & 2 & 3 & 4 & 5 & 6 & 7 & 8 & 9 & 10 & 11 & 12 & 13 \\
\hline Quartzite fragments & & 40 & 60 & 45 & 52 & 31 & 60 & 61 & 47 & 55 & 66 & 60 & 62 & 60 \\
\hline Biotite and Muscovite & & 46 & 10 & 35 & 27 & 31 & 10 & 10 & 33 & 10 & 13 & 10 & 10 & 23 \\
\hline Calcite & $\alpha^{\circ}$ & 10 & 15 & 15 & 21 & 15 & 10 & 15 & 13 & 20 & 4 & 13 & 9 & 17 \\
\hline Amphibolite fragments & $\Xi$ & - & 5 & 5 & - & 7 & 10 & 5 & 7 & 5 & 9 & 5 & 10 & - \\
\hline Magnetite & $z$ & 4 & 5 & - & - & 3 & 5 & 6 & - & 5 & 3 & 7 & 4 & - \\
\hline Pyrite & & - & - & - & - & 3 & 5 & - & - & - & 5 & - & - & - \\
\hline Schist fragments & & - & 5 & - & - & 10 & - & 3 & - & 5 & - & 5 & 5 & - \\
\hline
\end{tabular}




\subsubsection{X-ray Diffraction (XRD)}

$\mathrm{X}$-ray diffraction $(\mathrm{XRD})$ is the primary instrument used for the identification and quantification of the mineralogy of crystalline compounds in rocks and sediments. Furthermore, this tool is essential for characterizing the nature of clay minerals that cannot be determined by any other methods $[3,16]$. The 10 collected samples during the second phase were sent to the Mineralogical Laboratory of Satbayev Institute of Geological Sciences, Kazakhstan, for XRD analysis, the results of which are shown in Table 4.

Table 4. X-ray diffraction results for the collected sand samples through the second phase.

\begin{tabular}{|c|c|c|c|c|c|c|c|c|c|c|c|}
\hline \multirow{2}{*}{ Minerals } & & \multicolumn{10}{|c|}{ Samples } \\
\hline & & T001 & T002 & T003 & T004 & T005 & T006 & T007 & T008 & T009 & T010 \\
\hline Quartz & & 53.2 & 45.0 & 41.6 & 41.5 & 45.9 & 34.4 & 51.1 & 42.9 & 31.0 & 44.0 \\
\hline Amphibole (tremolite) & & 16.8 & 19.0 & 23.7 & 28.2 & 24.7 & 33.6 & 17.6 & 24.2 & 25.4 & 32.9 \\
\hline Albite & & 15.7 & 20.0 & 20.0 & 18.4 & 14.9 & 18.5 & 22.4 & 23.3 & 24.9 & 17.4 \\
\hline Mica & $\stackrel{\circ}{\Xi}$ & 4.3 & 4.9 & 5.3 & 4.9 & 2.6 & 7.0 & 3.3 & 3.7 & 3.5 & 1.4 \\
\hline Feldspar & $\ddot{3}$ & 3.4 & 3.9 & 3.3 & 4.1 & 10.6 & 3.0 & 3.3 & 3.6 & 12.7 & 3.3 \\
\hline Calcite & & 2.7 & 3.0 & 2.6 & - & - & - & - & - & - & - \\
\hline Chlorite & & 2.0 & 2.2 & 3.4 & 2.8 & 1.3 & 3.5 & 2.3 & 2.4 & 2.5 & 1.1 \\
\hline Hematite & & 1.7 & 2.0 & - & - & - & - & - & - & - & - \\
\hline
\end{tabular}

\subsection{Physical-Mechanical Analysis}

\subsubsection{Sieve Analysis and Atterberg Limits}

Sieve analysis, also known as a gradation test, is used to assess and define the particle size distribution of granular materials. The procedure is carried out by passing the materials through a series of sieves with different meshes. The Atterberg limits test measures the critical water contents of fine-grained soils, and depending on the water contents, four types, solid, semi-solid, plastic, and liquid, are determined [18].

In this study, 10 samples collected during the second phase were sent for sieve analysis, Atterberg limits, and soil classification following the ASTM D-422, ASTM D-4318, and ASTM D-2487 standards (Table 1). The results show that all the samples are considered non-plastic. From the total number of samples, 8 of them were classified as silty sand (SM) due to high sand, silt, and clay content (more than 10\%). Two samples (T009 and T010) were classified as poorly graded sand with silt (SP-SM) and poorly graded sand (SP), respectively. These two samples were collected from the northeast of the study area close to the mountain hillside and rock bodies.

\subsubsection{Specific Gravity}

The specific gravity of soil and sands depend on the density of the minerals existing within the soil particles and is measured using the material to the weight of an equal volume of water $\left(\right.$ at $\left.20^{\circ} \mathrm{C}\right)$. A substance with a specific gravity varying between 2.60 and 2.80 contains inorganic materials, while a substance with the gravity of 2.75 and 3.0 is lateritic soil. Sand particles, due to the presence of quartz minerals, have gravity ranging from 2.65 to $2.67[19,20]$. In this study, 10 samples were tested for specific gravity, which were collected from different locations of the study area. The analysis was carried out under the ASTM-854 standards with T001 $=2.69, \mathrm{~T} 002=2.70, \mathrm{~T} 003=2.74, \mathrm{~T} 004=2.71, \mathrm{~T} 005=2.69$, $\mathrm{T} 006=2.71, \mathrm{~T} 007=2.71, \mathrm{~T} 008=2.70, \mathrm{~T} 009=2.69$, and $\mathrm{T} 010=2.69$.

\subsubsection{Soundness Test}

Soundness is the loss percentage of materials from an aggregate blend during the sodium or magnesium sulfate soundness test. The test was carried out in ASTM-C8, 
which estimates the resistance of an aggregate to weathering. It can be done on both coarse- and fine-grained aggregates. The maximum loss percentage range from $10 \%$ to $20 \%[21,22]$. Five sand samples randomly were selected for this test within the study areas, the results of which are shown in Table 5.

Table 5. Soundness test results for the selected samples collected during the second phase.

\begin{tabular}{|c|c|c|c|c|c|c|c|c|c|c|c|}
\hline \multirow{2}{*}{\multicolumn{2}{|c|}{ Sieve Size }} & \multicolumn{10}{|c|}{ Samples } \\
\hline & & & T001 & & T002 & & T004 & & T006 & & T009 \\
\hline Passing & Retained & $\begin{array}{c}\text { Loss } \\
\text { after } \\
\text { Test } \\
\% \\
\end{array}$ & $\begin{array}{l}\text { Weighte } \\
\text { d Loss \% }\end{array}$ & $\begin{array}{c}\text { Loss } \\
\text { after } \\
\text { Test } \\
\%\end{array}$ & $\begin{array}{c}\text { Weighted } \\
\text { Loss \% }\end{array}$ & $\begin{array}{c}\text { Loss } \\
\text { after } \\
\text { Test } \\
\%\end{array}$ & $\begin{array}{c}\text { Weighted } \\
\text { Loss \% }\end{array}$ & $\begin{array}{c}\text { Loss } \\
\text { after } \\
\text { Test } \\
\%\end{array}$ & $\begin{array}{c}\text { Weighted } \\
\text { Loss } \%\end{array}$ & $\begin{array}{c}\text { Loss } \\
\text { after } \\
\text { Test } \\
\%\end{array}$ & $\begin{array}{c}\text { Weighted } \\
\text { Loss } \%\end{array}$ \\
\hline$\# 50(.3 \mathrm{~mm})$ & $\# 100(0.15 \mathrm{~mm})$ & 26.4 & 12.8 & 13.2 & 6.4 & 15.0 & 7.3 & 3.8 & 1.8 & 50.6 & 24.6 \\
\hline$\# 30$ (.6mm) & $\# 50(3 \mathrm{~mm})$ & & & 3.3 & 0.8 & 15.7 & 4.0 & 4.9 & 1.2 & 27.4 & 6.9 \\
\hline$\# 16(1.18 \mathrm{~mm})$ & $\# 30(6 \mathrm{~mm})$ & & & & & 11.9 & 4.0 & 5.9 & 2.0 & & \\
\hline \multicolumn{2}{|c|}{ Total Soundness } & \multicolumn{2}{|r|}{12.8} & \multicolumn{2}{|r|}{7.2} & \multicolumn{2}{|r|}{15.3} & \multicolumn{2}{|r|}{5.1} & \multicolumn{2}{|r|}{31.4} \\
\hline
\end{tabular}

\subsubsection{Alkali-Silica Reaction Test}

The alkali-silica test is carried out to detect the potential of an aggregate used in concrete for undergoing alkali-silica reaction resulting in potentially deleterious internal expansion. Based on the X1 section ASTM C1260, expansions of less than $0.10 \%$ at 16 days after casting are indicative of innocuous behavior in most cases, while the expansions between 0.10 and $0.20 \%$ at 16 days, the aggregates are known to be innocuous and deleterious; meanwhile, the deleterious aggregates are characterized by the expansions of more than $0.20 \%$ at 16 days after casting [23,24]. The same five samples (T001, T002, T004, T006, and T009) tested for soundness were also selected for the alkali-silica reaction test in this study. The results show that the expansion of all aggregate samples is less than $0.1 \%$ after 16 days; therefore, these aggregates indicate innocuous behavior and have no alkali reaction potential.

\section{Results and Discussions}

The Taatrang Zar sand deposits have been used for the last several years for various construction purposes; however, no detailed testing was done to characterize the aggregate grading, mineralogical and chemical composition, and their resistance against weathering and other factors. In such cases, the use of sand may cause distinct problems from a construction and building perspective in the future. Considering the chemical and mineralogical composition results, the sand deposits of Dasht-e-Taatrang Zar contain various chemical elements and minerals. The most abundant element being Si which can be a significant indicator of the mineral silicon dioxide $\left(\mathrm{SiO}_{2}\right)$ in the form of quartz or quartzite fragments. After $\mathrm{Si}$, aluminum $(\mathrm{Al})$ has a high distribution ranging from $4.98 \%$ to $6.72 \%$. The iron content also is regularly distributed, increasing from the hillside to the mountains, according to the samples collected.

Based on the findings of X-ray diffraction (XRD) and Schlich analysis, quartz and quartzite fragments had the highest distribution with different ranges. The range is increasing from east to west within the study area. The Schlich analysis showed the highest distribution of carbonates that affect the quality and resistance of sands; however, the results from this analysis, due to the classical methods employed, are not as reliable as XRD, and therefore the actual distribution of carbonates contents was confined within the study area. The limited samples show the existence of carbonate distribution. 
Concrete strength is lowered with increasing silt contents present in fine aggregate used for the concrete production as the compressive strength of concrete decreases from $5 \mathrm{MPa}$ to $3 \mathrm{MPa}$ when the silt content of the fine aggregate increases from $7 \%$ to $9 \%$ [25]. The results from almost all of the samples showed a silty sand type with a higher than $10 \%$ content of silt and clay. The soundness test of the collected samples indicates that the deposits located within the central part encountered less loss (high soundness, <10\%) and were resistant against weathering processes, while the deposits close to the hillside and road crossing were characterized by moderate or high loss (moderate to less soundness, $>10 \%$ ). Considering the alkali-silica reaction test, the Taatrang Zar sand deposits were characterized as non-reactive and could be used for different construction purposes.

\section{Conclusions}

Following the objectives of the research, which is the determination of chemical, mineralogical composition, and physical-mechanical properties of Taatrang Zar sand deposits within the Qarabagh and Bagram districts in Afghanistan, comprehensive field works and sample collection were carried out. Three separate analyses (Schlich, XRD, and XRF) were conducted for the chemical and mineralogical composition of the collected samples and showed that the Taatrang Zar sand deposits were mostly composed of quartz and amphibole (tremolite) minerals. Existing quartz fragments within the sand are considered a significant mixture from a hardness and resistance perspective. Sieve analysis, specific gravity, soundness, alkali-silica reaction tests were performed for the characterization of the physical-mechanical properties of these deposits. The results of sieve analysis showed that these sands should be classified as silty sand and of a non-plastic type. The amount of silt and clay was more than $10 \%$ and may be considered with caution for the direct usage of the sand as a construction material. Therefore, it is highly recommended to take the required steps before using them for construction purposes. Sands from the central parts were considered more resistant than other parts close to the hills. Furthermore, the findings show that Taatrang Zar sand deposits are characterized as non-reactive sands, which can be an effective indicator to be used for different construction purposes. The sand deposits area has a simple geologic and geographic setting which may decrease the exploitation costs and somehow will affect the overall cost of construction projects. Meanwhile, the deposits have high potential as a supply of sand for the new Kabul city (Dehsabz) project in Kabul and to other adjacent provinces, e.g., Parwan and Kapisa.

Author Contributions: Conceptualization, Hemayatullah Ahmadi and Amir Mohammad Mosazai; methodology, Hemayatullah Ahmadi; software, Hemayatullah Ahmadi; validation, Hemayatullah Ahmadi, Atal Yousufi, and Amir Mohammad Mosazai; investigation, Hemayatullah Ahmadi; resources, Atal Yousufi; writing - original draft preparation, Hemayatullah Ahmadi; writing - review and editing, Amir Mohammad Mosazai; visualization, Atal Yousufi; supervision, Hemayatullah Ahmadi; project administration, Hemayatullah Ahmadi; funding acquisition, Hemayatullah Ahmadi. All authors have read and agreed to the published version of the manuscript.

Funding: This research was funded by HEDP (Higher Education Development Program) project of the ministry of higher education in Afghanistan.

Institutional Review Board Statement: Not applicable.

Informed Consent Statement: Not applicable.

Acknowledgments: The authors are grateful to Mohammad Hadi Asadi, lecturer of Engineering Geology and Hydrogeology Department, and other colleagues from the Geological Engineering and Exploration of Mines department of Kabul Polytechnic University for providing general supports during the field and lab works. Furthermore, the authors would like to thank John Shroder and Stephen Collett for their proofreading.

Conflicts of Interest: The authors declare no conflict of interest. 


\section{References}

1. Bayliss, P.; Levinson, A.A. MINERALOGICAL REVIEW OF THE ALBERTA OIL SAND DEPOSITS (LOWER CRETACEOUS, MANNVILLE GROUP). Bull. Can. Pet. Geol. 1976, 24, 211-224.

2. Dell, C.I. A STUDY OF THE MINERALOGICAL COMPOSITION OF SAND IN NORTHERN ONTARIO. Can. J. Soil Sci. 1963, 43, 189-200.

3. Khan, M.H.R.; Liu, J.; Liu, S.; Seddique, A.A.; Cao, L.; Rahman, A. Clay mineral compositions in surface sediments of the Ganges-Brahmaputra-Meghna river system of Bengal Basin, Bangladesh. Mar. Geol. 2019, 412, 27-36.

4. Haredy, R.; Ghandour, I. Geochemistry and mineralogy of the shallow subsurface red sea coastal sediments, Rabigh, Saudi Arabia: Provenance and paleoenvironmental implications. Turkish J. Earth Sci. 2020, 29, 257-279.

5. Miura, K.; Maeda, K.; Furukawa, M.; Toki, S. Mechanical characteristics of sands with different primary properties. Soils Found. 1998, 38, 159-172.

6. $\quad$ El Ghoraiby, M.; Park, H.; Manzari, M.T. Physical and Mechanical Properties of Ottawa F65 Sand. In Model Tests and Numerical Simulations of Liquefaction and Lateral Spreading; Springer International Publishing: Berlin/Heidelberg, Germany, 2020 ; pp. 45-67.

7. Anagnostopoulos, C.A.; Papaliangas, T.; Manolopoulou, S.; Dimopoulos, T. Physical and mechanical properties of chemically grouted sand. Tunn. Undergr. Sp. Technol. 2011, 26, 718-724.

8. Ajalloeian, R.; Yu, H.S.; Allman, M.A. Physical and mechanical properties of Stockton Beach sand. In Proceedings of the 7th Australia New Zealand Conference on Geomechanics: Geomechanics in a Changing World; National Conference Publication (Institution of Engineers, Australia): Barton, ACT, Australia, 1996; pp. 60-65.

9. Fischer Jochen. Zur Geologie des Kohe Safi bei Kabul (Afghanistan). N.Jb.Geol. Palaont. Abh 1971, 3,267-315.

10. Tapponnier, P.; Mattauer, M.; Proust, F.; Cassaigneau, C. Mesozoic ophiolites, sutures, and arge-scale tectonic movements in Afghanistan. Earth Planet. Sci. Lett. 1981, 52, 355-371.

11. Treloar, P.J.; Izatt, C.N. Tectonics of the Himalayan collision between the Indian Plate and the Afghan Block: A synthesis. Geol. Soc. Spec. Publ. 1993, 74, 69-87.

12. Karapetov, S.S.; Sorokin, Y.A.; Sytov, Y.N.; Chepela, V.F.; Abdullah, S.; Ashmat, A. Geological Structure of Kabul Town Region Report of Logar and Helmand Prospecting-Mapping Group in 1979-1981, Afghan Geological Survey, Kabul/Afghanistan, 1981.

13. Abdullah, S.H.; Chmyriov, V.M.; Dronov, V.I. Geology and mineral resources of Afghanistan. Br. Geol. Surv. Occas. Publ. No. 15. (Reprint 1980 English Transl. 1977 Russ. Publ. British Geological Survey, 2008.

14. Leven, E.J. Permian Stratigraphy and Fusulinida of Afghanistan with Their Paleogeographic and Paleotectonic Implications; Geological Society of America: Boulder, CO, USA, 1997.

15. Bohannon, R.G. Geologic and Topographic Maps of the Kabul North $30^{\prime} \times 60^{\prime}$ Quadrangle, Afghanistan. U.S. Geol. Surv. Sci. Investig. Map 2010, 3120, 34.

16. Loubser, M.; Verryn, S. Combining XRF and XRD analyses and sample preparation to solve mineralogical problems. S. Afr. J. Geol. 2008, 11, 229-238.

17. Wirth, K. X-Ray Fluorescence (XRF). Encycl. Biophys. 2013, 2781-2781.

18. Of N. Test Procedure for SIEVE ANALYSIS OF FINE AND COARSE TxDOT Designation : Tex-200-F. Texas DOT, 2008. № 30. pp. 1-10.

19. Bell, F.G. Engineering Geology; Elsevier, 2007.

20. Bell, F. Engineering Properties of Soils and Rocks; Elsevier, 2013.

21. Wang, G.C. Slag use in asphalt paving. In The Utilization of Slag in Civil Infrastructure Construction; Elsevier: Amsterdam, The Netherlands, 2016; pp. 201-238.

22. Ioannou, I.; Fournari, R.; Petrou, M.F. Testing the soundness of aggregates using different methodologies. Constr. Build. Mater. 2013, 40, 604-610.

23. Berra, M.; Mangialardi, T.; Paolini, A.E. Alkali-silica reactivity criteria for concrete aggregates. Mater. Struct. 2005, 38, 373-380.

24. Owsiak, Z. Testing alkali-reactivity of selected concrete aggregates. J. Civ. Eng. Manag. 2007, 13, 201-207.

25. Cho, S.W. Effect of silt fines on the durability properties of concrete. J. Appl. Sci. Eng. 2013, 16, 425-430. 